Annals of Plant Sciences

ISSN: 2287-688X

OPEN ACCESS

Review Article

\title{
Baccaurea ramiflora Lour.: Biochemical and ethnobotanical value with scope for bio-prospection
}

Biswadeep Gogoi*

Department of Botany, Gauhati University, Guwahati-781014, Assam, India.

Received: 2017-06-13; Accepted: 2017-06-18

\begin{abstract}
Baccaurea ramiflora Lour., a member of Euphorbiaceae family, is found in the tropical forests with wild distribution in India (Assam). The fruits are edible and the wood of the tree is use for making furniture. The present review work is an effort to revisit the scientific works done to evaluate the scope for bio-prospection of edible fruit of B. ramiflora. Research work has reported rich content of minerals and vitamin $C$ in the fruit. The plant has ethno-botanical uses in different countries of the world. Though it has many valuable properties, the plant is still an underutilized plant as its economic potentialities are still untapped. Since time immemorial, humankind has quest for identification and utilization of biological resources, which is crucial to the survival, adaptation, and evolution of the human species. The search for new sources of chemical compounds, genes, proteins, microorganisms and other products that have economic potential and can be obtain from the biological resources around us is bioprospecting. Bioprospecting can be an element of conservation of bio-resources if it can contribute in the generation of wealth through research and development $(R \& D)$ and alleviating poverty in bio-diversity rich regions. If underexploited and underutilized natural resources can be transform into potential economically, valuable products it may help in leading subsistence lifestyles in the remote biodiversity rich regions.
\end{abstract}

Keywords: Baccaurea ramiflora; Bio-prospection; Edible fruit; Ethno-botanical; Euphorbiaceae; Vitamin C.

\section{Introduction}

Baccaurea ramiflora Lour., commonly known as "burmese grape" is a flowering plant belonging to the family Euphorbiaceae. 'Baccaurea' is a term derived from Latin, which refers golden yellow colour of the fruits [1]. It is one of the important underexploited fruit crop, as it has remained confined mainly to backyard plantation and as forest plant. The plant is native to Southeast Asia region distributed along the sub-Himalayan tract, mostly from Nepal to Sikkim, Darjeeling hills, Arunachal Pradesh, Tripura, Assam, Bhutan, Burma, Penninsular Malaysia, Tibet and Andaman Islands [2]. It is slow growing, evergreen, dioecious, short to medium height shade loving plant, which flowers during summer month, and fruits mature during rainy season. The whole plant has medicinal value, and research carried out on its different parts like leaves, roots, seeds, fruits have proven health benefits. The fruit has nutritional benefits because of its high content of vitamin $\mathrm{C}$, protein and iron [3]. The plant also mentioned in different traditional system of medicine and reported in many ethno botanical uses.
Taxonomic Classification

\begin{tabular}{lll} 
Kingdom & - & Plantae \\
Division & - & Magnoliophyta \\
Class - & \multicolumn{2}{c}{ Magnoliopsida } \\
Order & - & Euphorbiales \\
Family & - & Euphorbiaceae \\
Genus & - & Baccaurea \\
Species & - & B. ramiflora Lour.
\end{tabular}

\section{Synonyms}

Baccaurea cauliflora Lour.

Baccaurea flaccida Müll.Arg.

Baccaurea oxycarpa Gagnep.

Baccaurea pierardi Wall.

Baccaurea propinqua Müll.Arg.

Baccaurea sapida (Roxb.) Müll.Arg.

Baccaurea wrayi King ex Hook.f.

Gatnaia annamica Gagnep.

Pierardia flaccida Wall.

Pierardia sapida Roxb.

\section{Common name}

$\begin{array}{lll}\text { Assamese } & - & \text { Leteku } \\ \text { Bengali } & - & \text { Bhubi, Latkan } \\ \text { English } & - & \text { Burmese grape } \\ \text { Hindi } & - & \text { Leteku } \\ \text { Thai } & - & \text { Mafai }\end{array}$

\footnotetext{
*Corresponding Author:

Biswadeep Gogoi,

Research Student, Department of Botany

Gauhati University, Guwahati

Assam -781014, India.

E-mail: biswa 406@,rediffmail.com
} 


\section{Habitat and Distribution}

It is slow growing, evergreen, dioecious, short to medium height shade loving plant. It is native to South East Asia region and is found distributed in the sub-Himalayan tract, mainly from Nepal to Sikkim, Darjeeling hills, Arunachal Pradesh, Tripura, Assam, Bhutan, Burma, Peninsular Malaysia, Tibet and Andaman Islands.

\section{Morphology}

Stem grey-brown in colour, branchlets hispid while young and become glabrescent in maturity.

Leaves are $9-15 \times 3-8 \mathrm{~cm}$ in dimension, leaf blade is obovate-oblong, oblanceolate or oblong in shape, papery, green in colour adaxially and yellowish green abaxially, glabrous on both surfaces, cuneate at base, margin is entire or shallowly repand, apex shortly acuminate to acute.

Flowers are small, dioecious, apetalous, many flowered, compound into raceme panicles.

Fruit is yellowish and velvety, $2-3 \mathrm{~cm}$ in diameter with leathery pericarp.

Seed embedded in pinkish white pulp.

\section{Ethnobotanical Uses}

Baccaurea ramiflora has been mention in the Chinese Dai medicine. It is use as an anti-inflammatory and painkiller in treatment of injuries, rheumatoid arthritis, cellulitis, abscesses etc. [4]. The fruit of the plant has religious importance as people used to pay their homage to Lord Jagannath during the Holy Chariot Procession by offering the fruits along with other rituals [5]. Young leaves of the plant used as vegetable or flavouring agent for curries and minced meat in Bangladesh [6]. The fresh bark of the plant chewed or juice taken orally for complaints of constipation in India [7]. The seeds of the plant produce a valuable dye called "annatto" which is used for colouring silk, cotton and other textile materials in orange [8].

\section{Phytochemical Profile}

Chemical profile of the fruit pulp of Baccurea ramiflora has provided an insight into the nutritive value of the wild edible fruit (Table 1). If we look into the proximate values, it contains $35.6 \%$ water, carbohydrate $51.9 \%$, protein, and fibre $5.58 \%$ and $20.4 \%$ respectively. If we see, the mineral value of the fruit it is abundant of magnesium (504mg), potassium (730mg), phosphorous (132mg), and iron $(100 \mathrm{mg})$ per $100 \mathrm{gm}$ of fruit pulp. It has a significant amount of ascorbic acid, which adds to the property of antioxidant [9, 10]. Vitamin $C$ is an electron donor and this property makes it a potent watersoluble antioxidant for human [11]. While low potassium intake related to hypertension, cardiovascular diseases, chronic kidney stone formation and low mineral density, high sodium intake has also been associated with hypertension, and cardiovascular diseases [12, 13]. World health organization (WHO) suggest a potassium intake of at least $3510 \mathrm{mg} /$ day and $<2 \mathrm{~g} /$ day sodium for adults [14, 15]. Baccaurea ramiflora fruit has the proper ratio of sodium and potassium, which can help in prevention of the non-communicable diseases significantly. The fruit is also rich in iron, which can help in alleviating the anaemic condition, which has high prevalence in India.

Table 1. Proximate Fruit Composition of Burmese grape, Baccaurea ramiflora per 100 gm of pulp $[9,10]$

\begin{tabular}{lcllll}
\hline \multicolumn{1}{c}{ Proximate } & $\mathbf{\%}$ & Minerals & $\mathbf{M g}$ & Vitamins & $\mathbf{M g}$ \\
\hline Water & 35.6 & Calcium & 75 & Ascorbic & 273 \\
Protein & 5.58 & Magnesium & 504 & & \\
Lipid & 0.73 & Phosphorus & 132 & & \\
Carbohydrate & 51.9 & Potassium & 730 & & \\
Fibre & 20.4 & Sodium & 35 & & \\
Ash & 3.85 & Iron & 100 & & \\
\hline
\end{tabular}

The total soluble solids (TSS) has an average of $10.5^{0}$ Brix, which shows the quality of the fruit juice in terms of dissolved solids (Table 2). Reducing and non-reducing sugar along with total sugar were recorded as $2.68 \%, 3.03 \%$ and $5.85 \%$ respectively which is balanced with acidity of $1.9 \%$ thus making the fruit neither to sour nor too sweet [16].

Table 2. Bio-chemical properties of Burmese grape fruits, Baccaurea ramiflora [16]

\begin{tabular}{clcc}
\hline S. No. & $\begin{array}{c}\text { Bio-chemical } \\
\text { Parameters }\end{array}$ & Range & $\begin{array}{c}\text { Average } \\
\text { Value }\end{array}$ \\
\hline 1 & Total soluble solids(TSS) & $9.4-13.8^{\mathbf{0}}$ Brix & $10.5^{\mathbf{0}} \mathrm{Brix}$ \\
2 & Total Sugar & $4.14-6.05 \%$ & $5.85 \%$ \\
3 & Reducing Sugar & $2.72-3.15 \%$ & $3.03 \%$ \\
4 & Non-reducing sugar & $1.35-2.76 \%$ & $2.68 \%$ \\
5 & Acidity & $1.8-2.2 \%$ & $1.9 \%$ \\
\hline
\end{tabular}

Baccaurea ramiflora oil content of seed is of 25 -wt percentage (Table 3). The seed oil has a low moisture content (0.103) which is a sign of good quality and its ability to resist contamination or rancidity [17]. Moisture plays significant role in the process transesterification of glyceride with alcohol in presence of catalyst [18]. Acid value is the weight of $\mathrm{KOH}$ in $\mathrm{mg}$ needed to neutralize the organic acids present in $1 \mathrm{~g}$ of seed oil. It is a measure of the free fatty acids present in it and the value (1.127) here reflects high fatty acid content in contrast to canola and soya oil whose acid value are 0.071 and 0.60 respectively [19]. Iodine value is a measure of the unsaturation of the fats and oils besides an indication of the oils stability and health properties. The higher the value, the greater amount of unsaturation. Baccaurea ramiflora iodine value found to be 80.32 whereas coconut oil, olive oil, has 10 and 81 respectively. The refractive index of the oil (1.4672) is greater than that of water (1.330) at room temperature and is in close range with palm kernel oil (1.449-1.451) and soyabean oil (1.4661470) which suggests the utility of the oil in studies relating to optics [20]. 
Table 3. Some physicochemical properties of Baccaurea ramiflora seed oil [20]

\begin{tabular}{clc}
\hline S. No. & \multicolumn{1}{c}{ Parameters } & Observed values \\
\hline 1 & Colour & Light brown \\
2 & Oil content $(\mathrm{wt} \%)$ & 25 \\
3 & Density $(\mathrm{g} / \mathrm{cm} 3)$ & 0.8674 \\
4 & Acid value $(\mathrm{mg} \mathrm{KOH} / \mathrm{g})$ & 1.127 \\
5 & Iodine value $(\mathrm{gI} / \mathrm{100} \mathrm{g})$ & 80.32 \\
6 & Refractive index & 1.4672 \\
7 & Moisture $(\%)$ & 0.103 \\
\hline
\end{tabular}

Characterisation of the fatty acids composition in percentage of total methylester of fatty acids (FAMEs) of Baccaurea ramiflora seed oil determined by gas chromatography analysis shows saturated fatty acids to be more than $60 \%$ viz. palmitic acid $(33.67 \%)$, stearic acid $(19.38 \%)$, and arachidic acid $(9.69 \%)$. Oleic (24.48) and 11-transeicoseoic (12.75) are the two unsaturated fatty acids recorded (Table 4). Most of these saturated fatty acids has commercial value in soap, detergent, cosmetic industries. Oleic and 11-transeicosenoic acid are monounsaturated omega-9 fatty acids. Hypotensive effect of olive oil may be due to oleic acid [21]. Omega-9 fatty acids can help reduce the risk of cardiovascular disease and stroke by increasing high-density lipids (HDL) cholesterol and decreasing low-density lipids (LDL) cholesterol which help eliminating building up of plaques in arteries, which cause heart attack or stroke [22].

Table 4: Fatty acid Profile of Baccaurea ramiflora seed oil [20]

\begin{tabular}{lc}
\hline Saturated Fatty Acid & \% Composition \\
\hline Palmitic Acid & 33.67 \\
Stearic Acid & 19.38 \\
Arachidic Acid & 9.69 \\
\hline Unsaturated Fatty Acid & \\
\hline Oleic Acid & 24.48 \\
11-transeicosenoic & 12.75 \\
\hline
\end{tabular}

\section{Bioprospection}

Bioprospecting term indicate the search for new sources of chemical compounds, genes, proteins, microorganisms, and other products that have economic potential and that can be obtained from the biological resources around us.

The chemical profile of the fruit shows the nutritive value of this underutilized fruit, which can used to disseminate awareness about the fruit and will help in marketing. According to WHO noncommunicable diseases (NCDs) are the prime cause of mortality and morbidity globally, and prevention of NCDs are highly cost-effective. This fruit, which has a balance amount of minerals and vitamins, if commercially exploited following scientific principles can be a golden fruit for the economy and health of the people.

Total soluble solid and sugar content improved through application of molecular biology or breeding techniques will make it more attractive for the food processing and brewing industry. The oil content of the seed is also significant. The saturated fatty acid and omega- 9 fatty acids can be utilised in health, cosmetics and other industries.

\section{Conclusion}

Baccaurea ramiflora, mostly found in tropical forests with wild distribution, can be a prized fruit because of its nutritive value and its scope for bioprospection. The plant has numerous ethno botanical uses in different countries of the world. From being a rich source of vitamin $\mathrm{C}$, which has established antioxidant property, the fruit is rich in minerals, which can help eradicating many of the non-communicable diseases at a very cost-effective way. Fruit pulp has the blend of sweet and sour, which can be commercialize by the food processing and brewing industry. Seed oil can also be extracted and commercially exploited, as it has shown presence of omega- 9 fatty acids and other fatty acids of commercial importance in it.

Thus, this review attempted to highlight the economic potential of this underutilized fruit for bio prospection, which will help in conservation of the bio resources if it can contribute in the generation of wealth through R\&D and alleviation of poverty in the biodiversity rich regions.

\section{Acknowledgement}

The author is grateful to the authorities of Department of Botany, Gauhati University for their support.

\section{References}

1. Deb P, N Bhowmick. "Physico-chemical properties of burmese grape (Baccaurea sapida Muell. Arg.)- An underutilized fruit crop of West Bengal." International Journal of Agriculture and Food Science Technology. 4. 5 (2013): 415-420.

2. Sundriyal M, RC Sundriyal. "Underutilized edible plants of the Sikkim Himalaya: need for domestication." Curr. Sci. 85. 6 (2003): 731-736.

3. Peter KV. Underutilized and underexploited horticultural crops. Vol. 2, New India Publishing Agency, N. Delhi, India. (2007).

4. Lin YF, Z Yi, YH Zhao. Chinese dai medicine colourful illustrations. 1st ed., Yunnan National Publishing House, Kunming, China. (2003).

5. Goyal AK, T Mishra, A Sen. "Antioxidant profiling of Latkan (Baccaurea ramiflora Lour.) wine." Indian Journal of Biotechnology. 12 (2013): 137-139.

6. Hasan SMR, MM Hossain, R Akter, M Jamila, MEH Mazumdar, S Rahman. "DPPH free radical scavenging activity of some Bangladeshi medicinal plants." Journal of Medicinal Plants Research. 3. 11 (2009): 875-879. 
7. Khan B. Encyclopedia of Flora and Fauna of Bangladesh. 1st ed., Vol.7, Asiatic Society of Bangladesh, Dhaka. (2008).

8. Abdullah ATM, MA Hossain, Bhuiyan MK. "Propagation of latka (Baccaurea sapida Muell. Arg.) by mature stem cutting." Research Journal of Agricultural and Biological Sciences. 1. 2 (2005): 129-134.

9. Sundriyal M, RC Sundriyal. "Wild edible plants of the Sikkim Himalaya: nutritive value of selected species.” Economic Botany. 58 (2004): 286-299.

10. Kermasha S, NN Barthakur, NK Mohan, NP Arnold. "Chemical composition and proposed use of two semi-wild tropical fruits." Food Chemistry. 26. 4 (1987): 253-259

11. Padayatty SJ, A Katz, Y Wang, P Eck, O Kwon, JH Lee, S Chen, C Corpe, A Dutta, SK Dutta, M Levine. "Vitamin $\mathrm{C}$ as an antioxidant: evaluation of its role in disease prevention." J Am Coll Nutr. 22. 1 (2003): 18-35.

12. Whelton PK, J He, JA Cutler, FL Brancati, LJ Appel, D Follmann, MJ Klag. "Eddects of oral potassium on blood pressure. Meta-analysis of randomized controlled clinical trials." Journal of American Medical Association. 277. 20 (1997): 16241632.

13. Bibbins-Domingo K, GM Chertow, PG Coxson, A Moran, JM Lightwood, MJ Pletcher, L Goldman. "Projected effect of dietary salt reductions on future cardiovascular disease." New England journal of Medicine. 362.7 (2010): 590-599.

14. WHO. Guideline: Potassium intake for adults and children. World Health Organization, Geneva, Switzerland. (2012).

15. WHO. Guideline: Sodium intake for adults and children. World Health Organisation, Geneva, Switzerland. (2012).
16. Bhowmick N. "Latka (Baccaurea sapida Muell. Arg.), an underutilized food crop of Cooch Behar district of West Bengal, an option for income generation." Green Technology. 9 (2010): 64-67.

17. Akoh CC. Food lipids: Chemistry, nutrition and biotechnology. In Akoh CC, Min DB. (Ed). Lipidbased synthetic fat substitutes. Marcel Dekker, Inc., USA. (1998):559-588.

18. Lennie TA, DK Steward. "Balance between $n-6$ and n-3 fatty acids and the risk of coronary heart disease: The editorial opinions." Nutrition. 17. 9 (2001): 741742 .

19. Kardash E, YI Tur'yan. "Acid value determination in vegetable oils by indirect titration in aqueousalcohol media." Croat Chem Acta. 78. 1 (2005): 99103.

20. Dutta K, S Basumatary, DC Deka. "Physicochemical properties of Baccaurea ramiflora (Letuk) seed oil." Journal of Chemical and Pharmacentical Research. 5. 9 (2013): 210-218

21. Teres S, G Barcelo-Coblijn, M Benet, R Alvarez, R Bressani, JE Halver, PV Escriba. "Oleic acid content is responsible for the reduction in blood pressure induced by olive oil." Proceedings of the National Academy of Sciences. 105. 37 (2008): 13811-6.

22. Okuyama H, Y Ichikawa, Y Sun, T Hamazaki, WE Lands. "Omega3 fatty acids effectively prevent coronary heart disease and other late-onset diseases: the excessive linoleic acid syndrome." World Rev Nutr Diet. 96 (2007): 83-103.

\section{Cite this article as:}

Biswadeep Gogoi. Baccaurea ramiflora Lour.: biochemical and ethnobotanical value with scope for bio-prospection. Annals of Plant Sciences, 6.7 (2017) pp. 1649-1652.

doi: http://dx.doi.org/10.21746/aps.2017.07.001

Source of support: Department of Botany, Gauhati University, Guwahati, Assam, India. 